\title{
STUDI MISKONSEPSI MEDAN MAGNETIK MENGGUNAKAN METODE FOUR TIER TEST UNTUK SISWA SMA KELAS XII
}

\author{
Diajeng Ramadhan ${ }^{\text {a) }}$, Immanuel Bobby' Mudammirotul Ashnam' Resti \\ Alfianda, Mangasi A. Marpaung, Iwan Sugihartono ${ }^{\text {b) }}$ \\ Program Magister Pendidikan Fisika, Fakultas Matematika dan Ilmu Pengetahuan Alam, Universitas Negeri \\ Jakarta, Jalan Rawamangun Muka No. 1 - Rawamangun, Pulogadung, Jakarta Timur 13220 \\ Email: ${ }^{\text {a) }}$ ramadhan.diajeng@gmail.com, b)iwan-sugihartono@unj.ac.id
}

\begin{abstract}
Abstrak
Miskonsepsi adalah salah satu penyebab kesulitan belajar pada peserta didik, terutama pada pembelajaran fisika. Miskonsepsi dikalangan peserta didik perlu didiagnosis dan hasilnya dapat digunakan untuk meningkatkan hasil belajar. Penelitian ini bertujuan untuk mengidentifikasi miskonsepsi siswa pada materi medan magnetik menggunakan teknik four-tier diagnostic test. Four-tier test merupakan instrumen penilaian untuk menentukan konsepsi siswa, dalam memberikan jawaban yang tepat untuk pertanyaan dengan memahami alasannya. Four-tier test memiliki empat tingkatan. Tingkat pertama adalah pertanyaan pengetahuan berupa pilihan ganda, tingkat kedua adalah pertanyaan tentang keyakinan atas jawaban pada tingkat pertama, tingkat ketiga adalah penyajian alasan jawaban pada tingkat pertama, dan tingkat keempat adalah pertanyaan tentang keyakinan atau confidence rating atas alasan jawaban pada tingkat ketiga. Penelitian ini menggunakan metode penelitian deskriptif kuantitatif dengan teknik pengambilan sampel purposive sampling yang dilakukan pada 40 siswa kelas XII di salah satu SMA Swasta di Jakarta Timur untuk pokok bahasan medan magnet. Purposive sampling digunakan untuk membedakan siswa memahami konsep dengan siswa yang mengalami miskonsepsi.
\end{abstract}

Kata-kata kunci: miskonsepsi, medan magnetik, four-tier diagnostic test

\begin{abstract}
Misconception is one of the barriers for students in learning, especially in physics. Misconceptions among students need to be diagnosed so the results can be used to improve the learning outcomes. This research aims to identify students' misconceptions in magnetic field topic by using four-tier diagnostic test. The four-tier test is an assessment instrument to determine the depth of students' concepts in giving the correct answer to a question by understanding the reason. The test has four tiers of diagnosis. The first tier is the answer tier in the form of multiple choice questions, the second tier is the confidence rating of students in the correctness of their chosen options for the answer tier, the third level is the reason tier which presents the reason of the first tier, and the fourth level is the confidence rating of students in the reason tier. This research used quantitative descriptive method of analysis and purposive sampling technique. This research was conducted to 40 students of grade XII that had learned about the magnetic field's topic in one of the Private High Schools in East Jakarta. Purposive sampling was used to distinguish the students who understand the concepts with the students who experience misconception.
\end{abstract}

Keywords: misconception, magnetic field, four-tier diagnostic test 


\section{PENDAHULUAN}

Fisika merupakan cabang ilmu pengetahuan alam yang mempelajari tentang fenomena materi, energi, dan interaksinya. Disadari atau tidak, fisika memainkan peran penting dalam menentukan masa depan umat manusia. Hal ini dikarenakan banyak sekali penemuan dalam bidang teknologi yang berasal dari pengembangan ilmu fisika. Mengingat pentingnya peran fisika bagi umat manusia, maka proses pembelajaran fisika di sekolah harus berlangsung dengan baik, dalam hal ini penanaman dan penerapan konsep fisika kepada peserta didik haruslah tepat.

Dalam fisika, banyak sekali konsep pembelajarannya, sehingga salah satu tantangan yang sering ditemukan dalam pembelajaran fisika adalah miskonsepsi. Miskonsepsi didefinisikan sebagai kesalahan pemahaman yang mungkin terjadi selama atau sebagai hasil dari pengajaran yang baru saja diberikan, berlawanan dengan konsepsi-konsepsi ilmiah yang dibawa atau berkembang dalam waktu lama [8]. Sedangkan Berg, 1991 mendefinisikan miskonsepsi sebagai konsep-konsep yang tidak sesuai dengan konsepsi yang sekarang diterima para ilmuwan, padahal pikiran tersebut dibangun sesudah memperoleh pelajaran formal [2].

Faktor penyebab miskonsepsi diperoleh dari analisis reasoning terbuka pada setiap soal yang dikerjakan siswa di dalam pre-test (tes diagnostik). Beberapa indikator yang digunakan untuk mengetahui penyebab miskonsepsi yang berasal dari dalam diri siswa meliputi: a) bahasa sehari-hari siswa, b) asosiasi siswa, c) intuisi siswa yang salah, d) pandangan manusiawi, e) pengalaman [1].

Miskonsepsi pada peserta didik dapat berasal dari miskonsepsi guru, pengetahuan awal peserta didik yang salah, penalaran logika peserta didik yang terbatas, dan penggunaan sumber-sumber ilmu pengetahuan yang tidak valid. Oleh karena itu, identifikasi terhadap miskonsepsi telah menjadi langkah yang penting untuk mendapatkan pemahaman tentang pembelajaran peserta didik. Dengan teridentifikasinya miskonsepsi pada peserta didik, maka proses dalam pembelajaran dapat diperbaiki untuk menghilangkan miskonsepsi peserta didik, sehingga hasil pembelajaran dapat menjadi maksimal.

Salah satu cara untuk mengetahui miskonsepsi pada siswa adalah dengan tes diagnostik. Penggunaan tes diagnostik di awal maupun di akhir pembelajaran dapat membantu guru menemukan miskonsepsi siswa pada materi yang dipelajari [7]. Tes diagnostik yang baik dapat memberikan gambaran akurat mengenai miskonsepsi yang dialami siswa berdasarkan informasi kesalahan yang dibuatnya. Pertanyaan diagnostik yang baik tidak hanya menunjukkan bahwa siswa tidak memahami bagian materi tertentu, akan tetapi juga dapat menunjukkan bagaimana siswa berpikir dalam menjawab pertanyaan yang diberikan meskipun jawaban mereka tidak benar [6].

Identifikasi terhadap miskonsepsi dapat dilakukan dengan metode four-tier diagnostic test yang dilakukan pada 40 siswa kelas XII di salah satu SMA Swasta di Jakarta Timur untuk pokok bahasan medan magnet. Topik medan magnet dipilih dalam penelitian ini karena sifatnya yang abstrak atau sulit untuk dibayangkan karena tidak dapat dilihat dengan kasat mata. Topik yang sifatnya abstrak mempunyai peluang besar dalam menimbulkan miskonsepsi pada peserta didik.

Penelitian ini berdasarkan dengan beberapa penelitian yang relevan yaitu Ery Setianingsih dalam skripsinya tahun 2018, meneliti tentang miskonsepsi pada topik medan magnet dengan menggunakan metode three-tier test. Subjek dalam penelitiannya adalah siswa kelas XII SMA Negeri di Jember yang telah memperoleh materi medan magnet. Instrumen yang digunakan dalam penelitian ini adalah soal tes diagnostik miskonsepsi tentang materi medan magnet yang terdiri dari 12 butir soal yang diadaptasi dari soal Ujian Nasional yang telah divalidasi dan pedoman wawancara siswa untuk mengetahui penyebab miskonsepsi siswa. Berdasarkan hasil penelitian diketahui bahwa masih banyak siswa yang mengalami miskonsepsi pada materi medan magnet. Persentase siswa kelas XII SMAN di kabupaten Jember yang mengalami miskonsepsi pada konsep medan magnet yaitu sebesar $64,46 \%$. Adapun penyebab miskonsepsi siswa yaitu kemampuan siswa serta minat belajar siswa yang kurang [11]. 
Pada tahun 2017, Dedah Siti Jubaedah, Ida Kaniawati, Iyon Suyana, Achmad Samsudin, dan Endi Suhendi dari Universitas Pendidikan Indonesia, melakukan penelitian pengembangan tentang tes diagnostik miskonsepsi topik usaha dan energi pada siswa SMA Negeri di kota Bandung. Format tes yang digunakan adalah four-tier test dengan model 4D (Defining, Designing, Developing, and Disseminating). Proses tersebut dilakukan dengan memberikan tes sebanyak 15 soal dimana tes tersebut terdiri dari pertanyaan, alasan terbuka, dan tingkat keyakinan. Berdasarkan analisis data diperoleh persentase siswa yang mengalami miskonsepsi untuk seluruh soal pada topik usaha energi sebesar $38,22 \%$, namun pada penelitian ini tidak disebutkan penyebab umum miskonsepsi pada siswa-siswa tersebut [4].

Sedangkan, Qisthi Fariyani, Ani Rusilowati, dan Sugianto, pada tahun 2017 melakukan penelitian dengan judul "Four-Tier Diagnostic Test to Identify Miscopnceptions in Geometrical Optics". Penelitian ini dilakukan kepada 107 siswa kelas X yang telah belajar tentang optika geometri. Data penelitian ini dikumpulkan dari wawancara, kuesioner, dan tes. Wawancara dengan guru fisika dilakukan untuk mengetahui sejauh mana evaluasi diterapkan oleh guru bersama dengan tanggapan mereka terhadap four-tier test. Wawancara juga dilakukan kepada siswa untuk mengkonfirmasi jawaban mereka dalam melakukan tes. Sebuah kuesioner diberikan kepada siswa untuk mengetahui tanggapan mereka terhadap tes diagnostik empat tingkat. Data penelitian ini dianalisis dan diinterpretasikan untuk membedakan siswa yang memahami konsep, tidak memahami, dan miskonsepsi. Hasil penelitian menunjukkan bahwa pada setiap item tes, ada beberapa siswa yang memiliki miskonsepsi. Siswa memiliki miskonsepsi dalam kategori rendah dengan perincian $31 \%$ dari semua soal, 53\% dalam kategori sedang, dan 16\% dalam kategori tinggi [9].

Metode four-tier diagnostic test yang digunakan menjadi keunggulan dalam penelitian ini, karena metode ini merupakan penyempurnaan dari metode three-tier test, dengan tambahan satu tingkatan, yaitu pertanyaan tentang keyakinan penalaran (reasoning). Four-tier test memiliki empat tingkatan. Tingkat pertama adalah pertanyaan pengetahuan berupa pilihan ganda, tingkat kedua adalah pertanyaan tentang keyakinan atas jawaban pada tingkat pertama, tingkat ketiga adalah penyajian alasan jawaban (penalaran/reasoning) pada tingkat pertama, dan tingkat keempat adalah pertanyaan tentang keyakinan atau confidence rating atas alasan jawaban pada tingkat ketiga [3].

Menurut penelitian yang dilakukan Qisthi Fariyani tes diagnostik empat tingkat memiliki keunggulan sehingga guru dapat: (1) membedakan tingkat keyakinan jawaban dan tingkat keyakinan alasan yang dipilih siswa sehingga dapat menggali lebih dalam tentang kekuatan pemahaman konsep siswa, (2) mendiagnosis miskonsepsi yang dialami siswa lebih dalam, (3) menentukan bagian-bagian materi yang memerlukan penekanan lebih, (4) merencanakan pembelajaran yang lebih baik untuk membantu mengurangi miskonsepsi siswa [10]. Metode ini diharapkan dapat memberikan hasil penelitian yang valid dan dapat menjadi pedoman untuk studi miskonsepsi bagi topik-topik fisika yang lain ataupun untuk mata pelajaran yang lain.

\section{METODOLOGI}

Metode penelitian yang digunakan adalah deskriptif kuantitatif. Metode ini digunakan untuk mengambil data kemudian diolah dan dianalisis untuk memperoleh gambaran jumlah kuantitas siswa yang miskonsepsi pada materi medan magnet [12]. Populasi dalam penelitian ini diberikan pada siswa SMA swasta di Jakarta Timur. Teknik pengambilan sampel dalam penelitian ini adalah purposive sampling dan sampel dalam penelitian adalah 40 siswa kelas XII yang sudah mempelajari materi medan magnet di tingkat SMA. Tahapan penelitian yang dilakukan yaitu sebagai berikut: 


\section{Tahapan Pendahuluan Analisis Kebutuhan}

Peneliti menganalisis silabus dan perangkat pembelajaran sehingga didapat materi miskonsepsi medan magnet, penyusunan kisi-kisi soal tes, menganalisis setiap butir soal medan magnet dan memilih butir-butir soal yang sesuai dengan kompetensi dasar 3.3.

\section{Tahapan Desain Instrumen dan Menentukan Option Jawaban}

Setelah melewati tahap analisis kebutuhan, peneliti mendesain instrumen four-tier test yang menggunakan format pilihan ganda empat tingkat. Pada tahap menentukan option jawaban, peneliti melakukan studi literatur untuk menentukan pilihan jawaban four-tier diagnostic test mendiagnosis miskonsepsi siswa. Secara garis besar produk four-tier diagnostic test pada penelitian ini dapat dilihat pada TABEL 1 .

TABEL 1. Garis Besar Produk Four Tier Diagnostic Test

Produk yang Dikembangkan

Kisi-kisi soal four-tier diagnostic test

Petunjuk pengerjaan soal

Soal four-tier diagnostic test

Kunci jawaban

Lembar jawaban

Pedoman penskoran

Pedoman interpretasi hasil

\section{Isi}

Sub pokok bahasan, indikator soal, kategori tingkatan soal, jumlah soal

Petunjuk bagi siswa dalam mengerjakan soal

Judul, mata pelajaran, kelas, pokok bahasan, waktu pengerjaan, soal-soal tes, pilihan jawaban, tingkat keyakinan memilih jawaban, pilihan alasan, tingkat keyakinan memilih alasan Nomor soal, pilihan jawaban dan pilihan alasan yang benar Nama, kelas, nomor absen, kolom nomor soal, kolom pilihan jawaban, tingkat keyakinan jawaban, kolom pilihan alasan, kolom tingkat keyakinan alasan

Pedoman dalam memberikan skor dan menentukan hasil tes Pedoman untuk mengklasifikasikan jawaban yang diberikan siswa

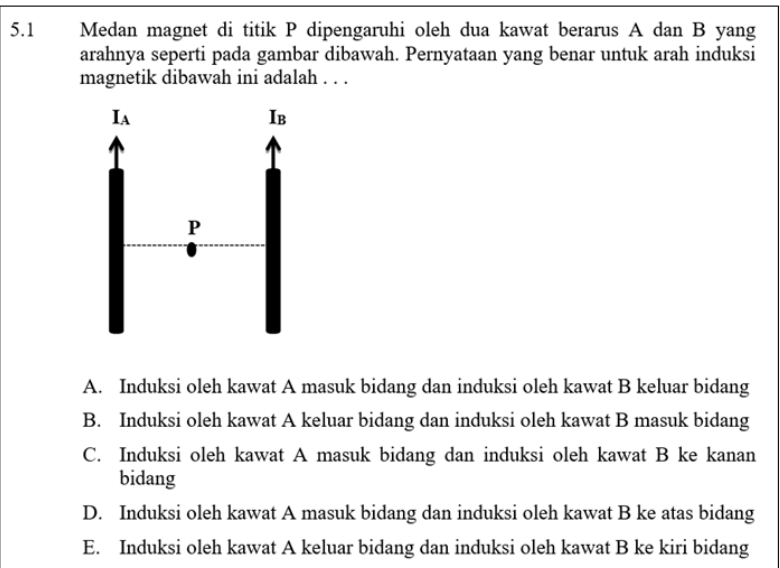

(a)

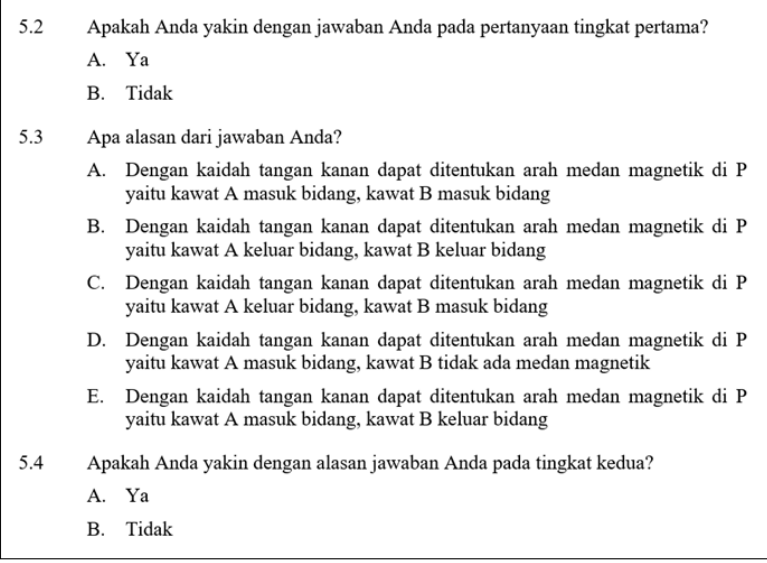

(b)

GAMBAR 1. Salah Satu Contoh Soal Dalam Four-Tier Test. (a) Soal Tingkat Satu (b) Soal Tingkat Dua Sampai Empat. 
Tahapan Uji Coba Four Tier Diagnostic Test dan Pengolahan Data

Pada tahap uji coba, instrumen soal medan magnet di uji coba kepada siswa SMA. Setelah melaksanakan uji coba, peneliti mengolah data untuk mengetahui tingkat konsepsi siswa. Metode pengumpulan data terdiri atas metode dokumentasi, wawancara, angket, dan tes. Wawancara dilakukan kepada guru untuk mengetahui pendapat guru mengenai four-tier diagnostic test yang dikembangkan dan kepada siswa untuk mengungkapkan pendapat mereka tentang konsep medan magnet secara bebas, sehingga guru dapat dengan mudah mengetahui miskonsepsi siswa dan mengetahui dari mana siswa memperoleh miskonsepsi tersebut melalui wawancara.

\section{Tahapan Analisis Data}

Analisis data yang dilakukan meliputi validitas, reliabilitas, interpretasi hasil four-tier diagnostic test, dan wawancara siswa yang mengalami miskonsepsi. Pengujian validitas menggunakan validitas isi yang dilakukan oleh dua dosen ahli. Pengujian reliabilitas menggunakan rumus Alpha Cronbach. Pengelompokkan tingkat konsepsi siswa dilakukan berdasarkan kombinasi jawaban pada four-tier test. Kombinasi jawaban four-tier test ini diadaptasi dari jurnal Zaleha, dkk (2017). Siswa dikelompokkan ke dalam kategori miskonsepsi (M), menguasai konsep (MK), menguasai sebagian konsep (MSK), tidak menguasai konsep (TMK), dan tidak dapat dikodekan (TDD). Adapun kategori dari jawaban four tier diagnostic test yaitu pada TABEL 2.

Setelah melalui uji validitas dari dua validator, instrumen diuji reliabilitasnya. Dari uji reliabilitas menggunakan SPSS, didaptkan bahwa nilai reliabilitas instrumen pada penelitian ini memiliki nilai $r$ $=0.500$, menurut Guilford (1956), nilai $\mathrm{r}$ ini menunjukan reliabilitas instrumen uji berada di tingkat yang moderat atau sedang.

Scale: ALL VARIABLES

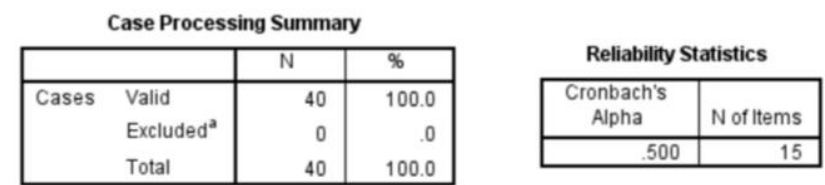

GAMBAR 2. Data Hasil Uji Reliabilitas Alpha Cronbach Menggunakan SPSS.

TABEL 2. Kombinasi Jawaban Four-Tier Diagnostic Test.

\begin{tabular}{|c|c|c|c|c|c|}
\hline \multirow[b]{2}{*}{ No } & \multirow{2}{*}{$\begin{array}{l}\text { Kategori } \\
\text { Konsepsi }\end{array}$} & \multicolumn{4}{|c|}{ Kombinasi Jawaban } \\
\hline & & Jawaban & $\begin{array}{c}\text { Tingkat } \\
\text { Keyakinan }\end{array}$ & Alasan & $\begin{array}{c}\text { Tingkat } \\
\text { Keyakinan }\end{array}$ \\
\hline 1 & Miskonsepsi (M) & Salah & Yakin & Salah & Yakin \\
\hline 2 & $\begin{array}{c}\text { Menguasai } \\
\text { Konsep (MK) }\end{array}$ & Benar & Yakin & Benar & Yakin \\
\hline 3 & \multirow{3}{*}{$\begin{array}{l}\text { Tidak Menguasai } \\
\text { Konsep (TMK) }\end{array}$} & Salah & Yakin & Salah & Tidak Yakin \\
\hline 4 & & Salah & Tidak Yakin & Salah & Yakin \\
\hline 5 & & Salah & Tidak Yakin & Salah & Tidak Yakin \\
\hline 6 & \multirow{5}{*}{$\begin{array}{c}\text { Menguasai } \\
\text { Sebagian Konsep } \\
\text { (MSK) }\end{array}$} & Benar & Yakin & Benar & Tidak Yakin \\
\hline 7 & & Benar & Tidak Yakin & Benar & Yakin \\
\hline 8 & & Benar & Tidak Yakin & Benar & Tidak Yakin \\
\hline 9 & & Benar & Yakin & Salah & Yakin \\
\hline 10 & & Benar & Yakin & Salah & Tidak Yakin \\
\hline
\end{tabular}




\begin{tabular}{|c|c|c|c|c|c|}
\hline 11 & & Benar & Tidak Yakin & Salah & Yakin \\
\hline 12 & & Benar & Tidak Yakin & Salah & Tidak Yakin \\
\hline 13 & & Salah & Yakin & Benar & Yakin \\
\hline 14 & & Salah & Yakin & Benar & Tidak Yakin \\
\hline 15 & & Salah & Tidak Yakin & Salah & Tidak Yakin \\
\hline 16 & $\begin{array}{c}\text { Tidak Dapat } \\
\text { Dikodekan (TDD) }\end{array}$ & A & dua & emu & tidak diisi \\
\hline
\end{tabular}

\section{Tahapan Evaluasi}

Pada tahap evaluasi, peneliti melakukan evaluasi terhadap instrumen yang telah dibuat dan di uji coba untuk dilakukan perbaikan dan sebagai saran untuk guru-guru fisika dalam mengajar materi medan magnet.

Instrumen tes miskonsepsi yang dikembangkan yaitu tipe empat tahap. Pada tahap pertama adalah pertanyaan pengetahuan tentang materi medan magnet, tahap kedua adalah pertanyaan tentang keyakinan atau confidence rating atas jawaban pada tingkat pertama, tahap ketiga adalah penyajian alasan jawaban pada tahap pertama, dan tahap keempat adalah pertanyaan tentang keyakinan (confidence rating) atas alasan jawaban pada tingkat ketiga. Dalam hal ini terdiri dari 15 butir soal.

Setelah hasil kombinasi jawaban selesai dianalisis, akan dilakukan wawancara kepada beberapa siswa yang mengalami miskonsepsi, agar diketahui penyebab miskonspsi mereka pada bahasan medan magnetik.

TABEL 3. Hasil Analisis Kombinasi Jawaban Four-Tier Test.

\begin{tabular}{ccccc}
\hline $\begin{array}{c}\text { Nomor } \\
\text { Soal }\end{array}$ & $\begin{array}{c}\text { Memahami } \\
\text { Konsep }(\%)\end{array}$ & $\begin{array}{c}\text { Memahami } \\
\text { Sebaian Konsep } \\
(\%)\end{array}$ & $\begin{array}{c}\text { Miskonsepsi } \\
(\%)\end{array}$ & $\begin{array}{c}\text { Tidak Memahami } \\
\text { Konsep (\%) }\end{array}$ \\
\hline 1 & 12,5 & 67,5 & 5 & 15 \\
2 & 2,5 & 50 & 10 & 37,5 \\
3 & 20 & 27,5 & 15 & 37,5 \\
4 & 22,5 & 47,5 & 2,5 & 27,5 \\
5 & 20 & 12,5 & 5 & 62,5 \\
6 & 17,5 & 52,5 & 2,5 & 27,5 \\
7 & 20 & 15 & 30 & 35 \\
8 & 20 & 32,5 & 25 & 22,5 \\
9 & 20 & 52,5 & 12,5 & 15 \\
10 & 20 & 17,5 & 5 & 57,5 \\
11 & 20 & 52,5 & 12,5 & 15 \\
12 & 27,5 & 25 & 15 & 32,5 \\
13 & 22,5 & 20 & 20 & 37,5 \\
14 & 22,5 & 22,5 & 17,5 & 37,5 \\
15 & 22,5 & 50 & 27,5 & 25 \\
\hline Rata- & 20 & 32 & 14,44 & 21 \\
Rata & & & & \\
\hline
\end{tabular}




\section{HASIL DAN PEMBAHASAN}

Instrumen four tier diagnostic test medan magnet divalidasi oleh ahli yaitu dosen pendidikan fisika UNJ yang kompeten dibidangnya. Studi awal miskonsepsi medan magnetik diperoleh berdasarkan hasil analisis kebutuhan yaitu menganalisis hasil nilai ulangan siswa pada 2 sekolah yang peneliti lakukan pada materi medan magnetik rata-rata siswa memperoleh nilai dibawah KKM yaitu 58-65. Penelitian ini dilakukan di SMA Wijaya Kusuma dan SMA Widya Mandala kelas XII pada tahun ajaran 2018/2019.

Berdasarkan data yang diperoleh dari kombinasi jawaban peserta didik pada instrumen four tier test mengenai materi medan magnet kemudian dilakukan pengolahan data, yang mana dari hasil perhitungan menunjukkan hasil yang berbeda-beda pada tiap soal yang diuji cobakan kepada peserta didik, soal disebar kepada 40 peserta didik dengan jumlah soal sebanyak 15 soal. Temuan hasil tersebut menunjukkan $20 \%$ peserta didik memahami konsep, $32 \%$ peserta didik memahami sebagian konsep, $14 \%$ peserta didik miskonsepsi, dan 21 peserta didik tidak memahami konsep. Berdasarkan tabel 3, dimana miskonsepsi tertinggi ada pada soal nomor 7. Miskonsepsi didapat adalah kebanyakan peserta didik menjawab bahwa $\frac{\mu_{0} I}{2 \pi r}$ dan arahnya tegak lurus keluar bidang gambar. Miskonsepsi lainnya adalah $\frac{\mu_{0} \mathrm{I}}{2 \mathrm{r}}$ dan arahnya tegak lurus keluar bidang gambar.

Miskonsepsi terendah ada pada soal nomor 4 dan 6 . Pada soal nomor 4 peserta didik menjawab Arah medan magnet tegak lurus terhadap medan listrik. Pada soal nomor 6. peserta didik menjawab bahwa I tetapi $\mathrm{N}$ dan $\mathrm{R}$ tetap dan $\mathrm{N}$ tetapi I dan R tetap, Jika (1) dan (3) yang benar. Pada soal nomor 5 terdapat kelompok yang tidak menguasai konsep. Hal ini dapat menjadi bahan analisis lebih lanjut untuk dilakukan evaluasi dan perbaikan. Perbaikan dilakukan dengan cara mengganti jawaban yang tidak dapat dipilih peserta didik dengan jawaban yang diberikan peserta didik pada opsi jawaban $\mathrm{f}$.

Berdasarkan hasil wawancara siswa, ditemukan sumber miskonsepsi antara lain: dari peserta didik itu sendiri yaitu mengenai intuisi yang berasal dari pengetahuan awal yang kurang, pernah melihat teman menyelesaikan soal saat belajar bersama, membaca buku, melihat penjelasan atau pembahasan soal-soal melalui media internet, dan hasil praktikum, bahkan faktor kelelahan fisik juga bisa terjadi sebagai salah satu penyebab miskonsepsi, karena fisik yang terlalu lelah sehingga daya konsentrasi menurun akibatnya terjadi kesalahan dalam mencerna informasi. Disamping itu juga karena adanya intuisi Menurut peserta didik, mereka kurang mampu menentukan arah medan magnet dengan menerapkan kaidah tangan kanan, juga sulit membedakan antara medan magnet dan medan listrik: mereka menganggap bahwa medan magnet sebagai medan listrik juga muatan positif dan negatif jika didekatkan akan saling tarik menarik berdasarkan hukum Coulomb. Selain itu peserta didik kesulitan jika menentukan gaya yang bekerja pada sisi panjang kawat yang membawa arus loop dalam medan magnet.

\section{SIMPULAN}

Berdasarkan hasil dan pembahasan dapat disimpulkan bahwa instrumen four tier diagnostic test medan magnet yang dikembangkan dapat mengelompokkan peserta didik kedalam kelompok menguasai konsep, menguasai sebagian konsep, miskonsepsi, dan tidak menguasai konsep. Hal ini menunjukkan bahwa instrumen ini dapat digunakan untuk meningkatkan hasil belajar peserta didik dan menjelaskan miskonsepsi medan magnet. Adapun evaluasi yang dilakukan menunjukkan perlunya dilaksanakan perbaikan serta pengembangan lebih lanjut, juga guru dapat mengetahui bagian mana saja materi medan magnetik yang memungkinkan terjadinya miskonsepsi pada peserta didik. Dengan demikian, guru dapat merencanakan proses kegiatan pembelajaran yang lebih baik untuk menanggulangi miskonsepsi yang dialami peserta didik, agar miskonsepsi yang terjadi tidak berkelanjutan pada pemahaman konsep materi yang saling berkaitan. 


\section{REFERENSI}

[1] Andrian, E. (2015). Remedi Miskonsepsi Beberapa Konsep Listrik Dinamis Pada Siswa SMA Melalui Simulasi PhET Disertai LKS . Jurnal Pendidikan Fisika, 3(4), 362 - 369.

[2] Berg, E. (1991). Miskonsepsi Fisika dan Remediasi. Salatiga: Universitas Kristen Satya Wacana.

[3] Caleon, I. S. (2010). Do Students Know What They Know and What They Don't Know? Using a Four-Tier Diagnostic Test to Assess the Nature of Students' Alternative Conceptions (Vol. 40). Res Sci Educ.

[4] Dedah Siti Jubaedah, I. K. (2017). Pengembangan Tes Diagnostik Berformat Four Tier Untuk Mengidentifikasi Miskonsepsi Siswa Pada Topik Usaha dan Energi. Prosiding Seminar Nasional Fisika. VI, pp. 35-40. Jakarta: UNJ.

[5] Ismiara Indah Ismail, A. S. (2015, Juni 8 - 9). Diagnostik Miskonsepsi Melalui Listrik Dinamis Four Tier Test. Simposium Nasional Inovasi dan Pembelajaran Sains, 381-384.

[6] Law, J. F. (2010). Diagnosis of Student Understanding of Content Specific Science Areas Using On-Line Two-Tier Diagnostic Tests. Australia: Curtin University of Technology.

[7] Lin, S. (2004). Development and Application of a Two-Tier Diagnostic Test for High School Students' Understanding of Flowering Plant Growth and Development. International Journal of Science and Mathematics Education, 2, 175-199.

[8] Mosik. (2010). Usaha Mengurangi Terjadinya Miskonsepsi Fisika Melalui Pembelajaran Dengan Pendekatan Konflik Kognitif. Jurnal Pendidikan Fisika Indonesia, 6, 98-103.

[9] Qisthi Fariyani, A. R. (2017). Four Tier Diagnostic Test To Identify Misconceptions In Geometrical Optics . UNNES Science Education Journal, 6(3), 1725-1729.

[10]Qisti Fariyani, A. R. (2015). Pengembangan Four Tier Diagnostic Test untuk Mengungkap Miskonsepsi Fisika Siswa SMA Kelas X. Journal of Innovative Science Education, 4(2), 4149.

[11]Setianingsih, E. (2018). Identifikasi Miskonsepsi Materi Medan Magnet Menggunakan Three Tier Test Pada Siswa SMA di Kabupaten Jember. Program Studi Pendidikan Fisika, Jurusan Pendidikan MIPA, Fakultas Keguruan dan Ilmu Pendidikan. Jember: Universitas Jember.

[12]Sugiyono. (2013). Metode Penelitian Pendidikan. Bandung: Alfabeta.

[13]Zaleha, dkk. (2017). Pengembangan Instrumen Tes Diagnostik VCCI Bentuk Four-Tier Test pada Konsep Getaran. Jurnal Pendidikan Fisika dan Kelimuan (JPFK), 3, 36-42. 